\title{
The Theme of Love in Various Pedagogical Concepts
}

Maja Hmelak*

maja.hmelak@um.si

https://orcid.org/0000-0002-8202-5572

Karakuma Samai**

karakuma.samai@student.um.si

https://orcid.org/0000-0002-3732-4186 https://doi.org/10.31192/np.19.1.11

UDK / UDC: 177.61:37.013

37.04

Pregledni članak / Review Primljeno / Received: 28. srpnja 2020. / Jul 28, 2020

Prihvaćeno / Accepted:

30. studenog 2020. / Nov. 30, 2020

The theme of love throughout history appears in many pedagogical concepts, where it has been researched in detail by various pedagogical theorists and practitioners, and many have also included it in their educational concepts. It is important from the point of view of the child and his involvement in the educational process itself and for proper introduction into the process itself, it requires an empathetic and professionally trained teacher and educator. Through a review of numerous scientific and professional works, the authors investigated the occurrence of the theme of love and found that it appears in many pedagogical concepts. These were presented in detail, critically evaluated and professionally analyzed and compared. They also found that the role of the teacher and educator and their example, which students and children follow, is crucial for the introduction of the theme of love.

Key words: child, educator, love, pedagogical concepts, teacher.

\footnotetext{
* Maja Hmelak, PhD, Assoc. Prof., University of Maribor, Faculty of Education; Address: Koroška cesta 160, SL-2000 Maribor, Slovenia.

**\%arakuma Samai, grad. educ of preschool children; postgrad. stud. of the Pedagogy program; University of Maribor; Faculty of Education; Address: Maistrova ulica 14, SL-1270 Litija, Slovenia.
} 


\section{Introduction ${ }^{* * * *}$}

The realization that the relationship to or love for the child (more precisely the child's soul) or the loved ones is a necessary paradigm that follows the teachings of life itself is becoming more and more valid. This indicates the need for a positively oriented development path in pedagogical concepts as well. Love is important, according to Peček and Lesar, ${ }^{1}$ because it causes a person to come out of loneliness and outdo himself. It is the only one to enable the confrontation of one spirituality with another, as well as the confrontation of the spiritual with the non-spiritual. Outdoing oneself is originally a human spiritual ability to devote oneself to a task other than oneself and its needs.

Gogala said that love, which is the main driving force of the mental bridge between teacher and student, only enables a living and genuine educational contact between them, which will make students open their souls to him. ${ }^{2}$ Whoever thus indulges in striving for someone or something, hears and also hears his requests, transcends himself, thus exceeding the limit of his own self. ${ }^{3}$ If we look at history, we can see that the Babylonians already associated love with a power that is able to transfer man to the world of culture and enables the spiritual development of man. ${ }^{4}$

So, what will the new upbringing and education in 21st century society look like? Love, as the highest competence of art, will have a driving role, but it will have to be well explained, predicts. ${ }^{5}$ To obtain educators-teachers who have this quality is one of the main problems nowadays. ${ }^{6}$ In this sense, Buscaglia ${ }^{7}$ points out that he is still waiting for a subject which would be taught from primary school to university and would be called Love.

\section{Methodology}

The purpose of the paper is to review the meaning and the role of love in education in the broadest sense through definitions of various pedagogical concepts by reviewing the relevant scientific and professional literature and synthesizing these findings.

\footnotetext{
\%*: Translation into English was made by Eliana Geržević Macan.

${ }^{1}$ Mojca PEČEK, Irena LESAR, Moč vzgoje: sodobna vprašanja teorije vzgoje, Ljubljana, Tehniška založba Slovenije, 2011, 14-50.

${ }^{2}$ Petra VONČINA, Pristno vzdušje vzgaja, in: Michele DE BENI (ur.), Biti vzgojitelj: izziv za prihodnost, Ljubljana, Novi svet, 2015, 111-119.

3 Peček, Moč vzgoje..., 49.

${ }^{4}$ Ibid, 50.

${ }^{5}$ Antonio PAVAN, Kakšna vzgoja za 21. stoletje?, in: De Beni (ur.), Biti vzgojitelj..., 82-92.

${ }^{6}$ Jiddu KRISHNAMURTI, Vzgoja in izobraževanje in pomen življenja, Maribor, Samozaložba D. Celar, 2000, 41-111.

${ }^{7}$ Leo F. BUSCAGLIA, Živimo, ljubimo in se učimo, Ljubljana, Znanka, 2004, 26.
} 
The paper is an in-depth scientific-theoretical discussion on the topic of love in various pedagogical concepts. In doing so, we wanted to: (1) define the role of love in general and in pedagogy, (2) determine the emergence of the theme of love in various pedagogical concepts, (3) highlight and critically evaluate the findings of many pedagogical classics and their works on the topic of love in the upbringing of a child.

Applied research methods: descriptive and comparative method and the method of analysis.

The data were collected through a systematic and in-depth review of relevant scientific and professional literature.

\section{The definition of love and the theme of love in pedagogy}

By definition, love means being open and free to feel and allow others this freedom. Allow others to be natural. Allow him to be what he is. ${ }^{8}$ Love is not simple, says Pavan. ${ }^{9}$ It has the roots in the search for justice and flourishes from a human point of view in selfless giving. In fact, it hides the intimate tendency to »return« as a gift our true original being: to the universe, life, people, freedom. V. E. Frankl likes to cite love as: to understand man in his essence, in his uniqueness and singleness. On a spiritual level, love opens a person's eyes, makes him a seer, because he sees value in the other and illuminates it. ${ }^{10}$

In education, love is most important. ${ }^{11}$ The question of the presence of love in education can be understood as a question of the emotional component in the process of shaping an individual's personality. ${ }^{12}$ Only in the freedom of the individual can love and goodness flourish; and proper upbringing and education can offer that freedom. ${ }^{13}$ In the field of transcendence (transcending existing mental, emotional, behavioural schemes), one must learn to combine the abilities of the mind with the power of love. This is demonstrated throughout European history by philosophers, mystics, theologians, artists, as well as great educators; despite the lack of completeness of the question of the concept of the pedagogical eros, I should mention Pestalozzi, Don Bosco, A.S. Neill and S. Gogalo. ${ }^{14}$ Gogala is the one who established the concept of pedagogical eros in the Slovenian pedagogy. In the case of pedagogical eros, however, it is the teacher's subjective assumptions of successful teaching and upbringing. The real pedagogical eros is the teacher's personal relationship to culture, his

\footnotetext{
8 Zvone KRUŠIČ, Aleksander S. Neill - zgled avtoritete?, Educa, 2 (1992) 1-2, 99-107.

${ }^{9}$ Pavan, Kakšna vzgoja..., 89.

${ }^{10}$ Peček, Moč vzgoje..., 49.

${ }^{11}$ Blaž FERLINC, Izzivi in pasti sodobne vzgoje, Šmarješke toplice, Stella, 2009, 62.

${ }^{12}$ Peček, Moč vzgoje..., 47.

${ }^{13}$ Krishnamurti, Vzgoja in izobraževanje..., 41.

${ }^{14}$ Robi KROFLIČ, Eros in vzgoja, Sodobna pedagogika, 50 (1999) 2, 224-236.
} 
spiritual love for it; to the teacher who is really an »educator «, the pedagogical work, in which he fully lives and personally indulges, is so dear that he cannot live without such a way of working. ${ }^{15}$ One of the most common demands that young people express in different ways is precisely the need to be in a relationship and to find a sense that will respond to their need for love. This is a profound requirement that cannot be limited to the family environment, but the school must also take responsibility for it. ${ }^{16}$

Love, which is the main driving force for the mental bridge between teacher and student, only enables a living and genuine educational contact between them, which will make students open their souls to him. ${ }^{17}$ The Greeks thought similarly. Socrates and Plato could not imagine the possibility of education and spiritual guidance without a loving contact between teacher and student. ${ }^{18}$ You must not allow fear to creep in between you and the child. Fear destroys upbringing. It gives birth to pretense and lies. Experience to date has shown that man must be allowed the freedom to stumble in his actions and to err in his cognition until he himself recognizes wrongdoing and error. Otherwise, it cannot grow, Pavitra. ${ }^{19}$

\section{The theme of love in various pedagogical concepts}

\subsection{Alexander Sutherland Neill and his Summerhill}

Alexander Sutherland Neill (born in Scotland in 1884) claims that love at his Summerhill school is the one that heals. In a way, we can say that the entire Summerhill staff always performs therapy - because one of the best ways of therapy is to be on the child's side.$^{20}$ Neill's upbringing does not take advantage of »classical authority«, which is based on fear and power over the child. He, as an educationist, represents such an authority that sets itself the goal of giving up its desire in relation to them, and thus the power over them. ${ }^{21}$ Teachers at Summerhill are just curious and guides that children consult. One of the essential tasks of a teacher in Summerhill is also to teach children how to learn. ${ }^{22}$ Neill understands that an authority that expresses love cannot rely on fear of a

\footnotetext{
${ }^{15}$ Robi KROFLIČ, Avtoriteta in pedagoški eros - temeljna koncepta Gogalove vzgojne teorije, Sodobna pedagogika, 51 (2000) 5, 56-83.

${ }^{16}$ Francesco Châtel, Učenci istega dobrega, in: De Beni (ur.), Biti vzgojitelj..., 100-105.

${ }^{17}$ Vončina, Pristno vzdušje..., 112.

${ }^{18}$ Peček, Moč vzgoje..., 50.

${ }^{19}$ PAVITRA, Šolanje in cilj človeškega življenja, Radovljica, Didakta, 2001, 80.

${ }^{20}$ Tatjana DEVJAK, Sanja BERČNIK, Majda PLESTENJAK, Alternativni vzgojni koncepti, Ljubljana, Pedagoška fakulteta, 2008, 87-129.

${ }^{21}$ Krušič, Neill..., 104.

${ }^{22}$ Devjak, Alternativni..., 128.
} 
child. He fully trusts in the child, believes in happiness and working with joy. He combines intellectual and mental education and establishes the connection of education with the psychological needs of children. ${ }^{23}$ First and foremost, the teacher should be a person who cares about students and their well-being, a person who educates and inspires and introduces the student to everything that has ever been said, made and invented (created) in the world. Here a good teacher allows the individual to find and fulfill himself. ${ }^{24}$ Therefore, his method relieves both the educator and the children. He says discipline and punishment create fear, and fear creates hatred. His students are called free children because of such a pedagogical concept. Their social success was average, but they showed a solid mental balance, which made them able to enjoy life. They are distinguished by a common feature: the independence of the spirit. ${ }^{25}$ And characteristic of this new world of love, their mutual complementary diversity, genuineness and authenticity - is above all a higher level of freedom. Thus, Neill is committed to faith in the good of the child. ${ }^{26}$

\subsection{Maria Montessori}

Maria Montessori only wanted to understand the child and, with her extraordinary gift of observing children, made discoveries that changed the view of the child, and thus the pedagogical approach ${ }^{27}$ Her pedagogical approach was very simple. Just look after them and let them choose for themselves what they will do and discover what can be done with the learning materials. The children were not shouted at, quarreled over, not punished, the children simply began to enjoy themselves. They became lively, got a healthy look and loved coming back endlessly. ${ }^{28}$ The Montessori approach is primarily learning for life; it fully includes self-motivation, self-discipline, self-knowledge. Her message is to raise the child through his needs, especially activities. A child imitates an adult, but for him it is only an impulse, a motivation to develop his intellect and spiritual life. ${ }^{29}$ At the level of educational work, Montessori introduced the principle that the learning process is more important than results, the child's right to choose activities and teammates, individual educational work, the importance of using

\footnotetext{
${ }^{23}$ Krušič, Neill..., 104.

${ }^{24}$ Devjak, Alternativni..., 129.

${ }^{25}$ Catherine MILLOT, Anti-pedagog Freud, in: Slavoj ŽIŽEK (ur.), Gospostvo, vzgoja, analiza, Ljubljana, Dopisna delavska univerza Univerzum, 1983, 184-217.

${ }^{26}$ Krušič, Neill..., 106-111.

${ }^{27}$ Maria MONTESSORI, Srkajoči um, Ljubljana, Uršulinski zavod za vzgojo, izobraževanje in kulturo, 2008, 7-14.

${ }^{28}$ Melita KORDEŠ DEMŠAR et al., Spodbujanje otrokove razvoja od 6. do 12. leta, Vzgoja, 65 (2015) 8-10.

${ }^{29}$ Montessori, Srkajoči..., 8-12.
} 
all the senses, the importance of practical activities and movement. ${ }^{30}$ She gives children freedom, the possibility of their own choice, and in this, she sees the possibility that the child lives in love. She says that the child just needs to feel that we love and accept him unconditionally, because that way he will be able to develop his potential. In addition to an environment suitable for its development capabilities. ${ }^{31}$ So, Montessori goes beyond usefulness, she is thoughtful and discovers the meaning of education - she connects the development and flourishing of the individual with the sociological views of the development and culture of all mankind. ${ }^{32}$ The teacher's function is to enable the relationship between the child and the distribution in the environment to foster the interaction between the child and the material. With his mental, scientific and technical readiness, he has the task of helping the project of development of each child and encouraging his or her propensity for independence. ${ }^{33}$

\subsection{Rudolf Steiner and Waldorf school}

Rudolf Steiner, the most powerful European clairvoyant researcher of spiritual worlds, philanthropist, thinker, scientist, philosopher, father of anthroposophy, sage and father of the Waldorf school was born in $1861 .{ }^{34} \mathrm{He}$ founded spirituality as a science. His selfless, correctly provides solutions for a fundamental understanding of man and humanity, as an exemplary continuation of the teachings of Christ. He describes that love is actually one of the virtues of the soul. ${ }^{35} \mathrm{He}$ emphasized that a person as an educator should be a person with a full personality, because only in this way can he develop awareness and not make mistakes in his relationship with children. His Waldorf school is based on anthroposophy, a special humanistic wisdom with which it is possible to penetrate to the human essence, but not with science, which remains predominantly on the empirical surface. ${ }^{36}$ Anthroposophists will not be content with merely preaching universal love. ${ }^{37} \mathrm{~A}$ holistic free personality is one of the main goals of Waldorf pedagogy. Here we meet again with some form of freedom. Through his attitude to work, the teacher encourages work habits in students that are not related to coercion, but to their own motivation to learn and knowledge.

\footnotetext{
${ }^{30}$ Devjak, Alternativni..., 91.

${ }^{31}$ Marcela BATISTIČ ZOREC, Dušan KRNEL, Prednost učenja pred poučevanjem, in: Tatjana DEVJAK, Darija SKUBIC (ur.), Izzivi pedagoškega koncepta Reggio Emilia, Ljubljana, Pedagoška fakulteta, 2009, 47-76.

${ }^{32}$ Montessori, Srkajoči..., 13.

${ }^{33}$ Devjak, Alternativni..., 87.

${ }^{34}$ Rudolf STEINER, Kdo duhovno vodi človeka in človeštvo?, Ljubljana, Garbo Unique, 2011, 7-14.

${ }^{35}$ Rudolf STEINER, Kristus in človeška duša, Ljubljana, Samozaložba J. Urbanc, 2016, 96-188.

${ }^{36}$ Marjan BLAŽIČ et al., Didaktika, Novo mesto, Visokošolsko središče, Inštitut za raziskovalno in razvojno delo, 2003, 38-39.

${ }^{37}$ Steiner, Kristus..., 100.
} 
Like Neill and Montessori, Steiner does not encourage coercion and pressure on students or children. Learning takes place without coercion, as well. Children learn out of curiosity and desire to understand the world ${ }^{38} R$. Steiner says that the interest that properly guides us together with the outside world must lead us and direct us in our love of the outside world. He not only promotes the development of cognitive abilities, but also the potentials of the heart and will. Therefore, handicrafts, arts and hand work play a significant role in the learning process. ${ }^{39} \mathrm{R}$. Steiner explains that the change of mental strength and courage is surrendered as true love. True love must then be guided by other virtues, other interests. He also says that love acts as something that must permeate the whole of life, including the whole of social life by arranging it. Faith, love, and conscience will be the three stars of moral forces that will be drawn into human souls by a particular anthroposophical worldview. The anthroposophical worldview is supposed to cultivate an ethical, moral life in the light of these virtues that will be the building forces in the future. ${ }^{40}$

\subsection{Loris Malaguzzi and the Reggio Emilia}

The founder of the Reggio Emilia approach, Loris Malaguzzi (1920-1994), offers help to children in developing their potentials and consciously encourages all forms of expression, not following a specific curriculum or plan, but the child. He proceeds from the desires of children and adults and does not set conscious goals in advance. They are constantly preparing various possible ways of implementing projects. Gradually, he concluded that things about children and for children can only be learned from the children themselves. They learn through communication and concrete experiences. ${ }^{41}$ His broad knowledge enabled Malaguzzi to boldly, independently formulate a modern concept as well as a good defense against many contradictions, as he was professionally well acquainted with various psychological theories and the results of foreign research. ${ }^{42} \mathrm{He}$ has also collaborated with other great educationists.

\subsection{Jan Amos Comenius (Komensky)}

Jan Amos Comenius (Komensky) is the greatest pedagogue of the $17^{\text {th }}$ century and the founder of the primary school, born in 1592 in Moravia. He was the first to consider theoretical knowledge of educational practice as an in-

\footnotetext{
${ }^{38}$ Nada ANTAUER et al., Waldorfska šola od A do Ž, Maribor, Waldorfska šola Ljubljana, 2011, $2-13$.

${ }^{39}$ Ibid, 2.

${ }^{40}$ Steiner, Kristus..., 105.

${ }^{41}$ Devjak, Alternativni..., 110.

${ }^{42}$ Ibid.
} 
dependent scientific science. ${ }^{43}$ His intention was to help people. He thought that it was first and foremost necessary to help young people by establishing schools as soon as possible, which would have good books at their disposal and where they would teach according to a good method, in order to revive science, virtue and piety. ${ }^{44}$ In order to apply his didactic principles in school practice, Comenius wrote several textbooks for primary and secondary school. He advocated that everyone should receive education. His schooling, which was based on a Christian orientation, was supposed to bring the human back home to 'Heaven'. ${ }^{45}$ The feeling of love is not perfect in people who do not know the revelation of God, explained J. A. Comenius. He insisted that as much as possible care should be taken to ensure that the way in which true morality and piety were infused into souls was carefully established in schools so that they would truly be workshops for humanity. ${ }^{46} \mathrm{He}$ saw the culmination of man's spiritual development in becoming one with this love, or ,merging' with it. In the Great Didactics, he wrote that faith, love, and hope are learned in practice, through firm belief in all that God has revealed, through work in all that $\mathrm{He}$ commands, and through hope in all that He promises. ${ }^{47} \mathrm{He}$ advocated the thesis that the best learning is one that takes place in as natural a way as possible. ${ }^{48}$ Comenius did not understand the teacher's work as a normal profession, but as a mission, a heavenly profession on which the development and progress of the whole society depends. ${ }^{49}$

\subsection{Tinka Podjavoršek}

Tinka Podjavoršek from Slovenia also has her own idea of a »joyful school«. She named it Eliza: E like ethics, emotions, empathy, L like love, I like intelligence, intellectuality, intuition, Z like zaupanje (Slov. trust), zmagam-zmagaš (Slov. I win - you win), A like action, assertiveness. ${ }^{50}$ She has a very critical view of materialistic education based on mechanical science, which requires too much in terms of quantitative data collection and too little in terms of qualitative, independent »accumulation « of knowledge to use in practice and physical work that would give us a sense utility. ${ }^{51}$ She wonders where children have role

\footnotetext{
${ }^{43}$ Peček, Moč vzgoje..., 50.

${ }^{44}$ Jan Amos KOMENSKY, Velika didaktika, Novo mesto, Pedagoška obzorja, 1995, 5-162.

${ }^{45}$ Ibid, 66.

${ }^{46}$ Ibid, 136-143.

${ }^{47}$ Ibid, 145-147.

${ }^{48}$ Gordon DRYDEN, Jeannette VOS, Revolucija učenja, Ljubljana, Educy, 2001, 93.

${ }^{49}$ Edvard PROTNER, Pedagogika in izobraževanje učiteljev (1919-1941), Nova Gorica, Educa, 2000, 12-119, 112.

${ }^{50}$ Tinka PODJAVORŠEK, Šola, najljubši in najradostnejši kraj za otroke, Ankaran, Samozaložba, 2007, 30-52.

${ }^{51}$ Podjavoršek, Šola..., 30-52.
} 
models and examples. Eliza is a loving process in which everything matures at the right time. And the most beautiful things happen when no one forces anything on anyone. According to her, the main emphasis is on joy, which is our natural state, as she said in an interview with the Slovenian magazine Sensa. The intention of unobtrusiveness can also be traced in the ELIZA concept.

\subsection{Johann Friedrich Herbart}

We should also mention Johann Friedrich Herbart (1776-1841), who in 1804 wrote a book entitled General Pedagogy. We consider him the founder of pedagogy as an independent scientific discipline, which he based on ethics and psychology. ${ }^{52}$ Even Herbart could not escape the classic requirement of raising children: he who wants to lead a child must first form authority and love in his own mentality. ${ }^{53}$ The chapter on real upbringing begins with the idea that art would be »worthy of the greatest hatred, « by which you »disturb a child's mentality in its peace, bind it to trust and love « to shape it as you like and incorporate it prematurely into »unrest of later years $«{ }^{54}$ However, we would not say here that tying someone to the unrest of later years is love at all. He further explains that authority must not limit a child's independence. It is similar with love, which makes leadership much easier because it imparts to the child the educator's spiritual orientation, which can at the same time lead to a devastating justification for violence against the child. ${ }^{55}$ We cannot agree that we are violent towards a child out of love in the pedagogical process. It is just an illusion that we can control the other and think we are acting out of love. But the child, like our mirror, shows us that this is not the case. So, Herbart writes a warning: do not over-educate.

\subsection{The spiritual or cultural pedagogy}

Basically, education is geared towards the good of the young person. In the spiritual or cultural pedagogy, the pedagogical relationship was interpreted as an interactional relationship in which the pupil is understood not only as an object, but also as a subject who has the right to co-create the pedagogical relationship. Of course, spirituality especially emphasizes love. The essence of the pedagogical relationship is that it is based on trust and pedagogical love. Therefore, this relationship cannot be created by coercion and manipulation. It is always based on free decision-making and at the same time on irrational

\footnotetext{
${ }^{52}$ Peček, Moč vzgoje..., 15.

${ }^{53}$ Edvard PROTNER, Herbartistična pedagogika na slovenskem (1869-1914), Maribor, Slavistično društvo, 2001, 44-46.

${ }^{54}$ Ibid, 46.

${ }^{55}$ Ibid, 45.
} 
components (affection, love, resistance) that evade rationalization. ${ }^{56}$ Spiritual pedagogy also sees a fundamental category of pedagogical sense in intuition, which is given to a large extent only to some who are born for pedagogical work, advocated also by S. Gogala. Therefore, the teacher needs additional education that would be related to life. ${ }^{57}$

\subsection{Jean Jacques Rousseau}

J. J. Rousseau also wrote that it is not the teacher's job to instill in the child the idea of adults and to teach him as much as possible, but to guide his natural curiosity and create the conditions for him to engage in his nature at every stage of his spontaneous development. The criteria for the content of lessons are therefore not social requirements, but the child's needs. ${ }^{58}$ According to Rousseau, the basic characteristics of human nature are: love of self, propensity for freedom, the ability to improve oneself, sociability and the pursuit of happiness or personal prosperity.$^{59}$ Rousseau demanded that the student take care of the material he would be dealing with. In other words, the child must be free during lessons and therefore, the teacher must adapt the lessons to individual students. ${ }^{60}$ Aware of the fact that love as a driving force of self-preservation and humanity can turn into self-love, Rousseau warns against an education in which adults would submit to children's whims or the desire for command and authority. The desire to please adults must not become a source of the child's adaptation to social circumstances. ${ }^{61}$ Rousseau can be described as one of the first theorists of education, who with the motto 'our real study is the study of human nature' drew attention to the importance of studying the developmental characteristics of the child. ${ }^{62}$ Rousseau is especially respected as a well-known cultural critic who advocated straightforwardness, simplicity and sensitivity. So, a simple and natural life as a path to happiness and self-satisfaction. ${ }^{63}$

The development of didactics from the 18th century to the present has shown that the principle of conformity of education with children's interests is the right principle to contribute to the development of the individual and society, if not taken absolutely, if we recognize and in practice consider the limits of

\footnotetext{
${ }^{56}$ Ibid, 38.

${ }^{57}$ Ibid, 49-119.

${ }^{58}$ Jean Jacques ROUSSEAU, Emil ali O vzgoji, Ljubljana, Zveza pedagoških društev v Sloveniji, Državna založba Slovenije, 1959, 10-40.

${ }^{59}$ Robi KROFLIČ, Rousseaujev koncept človečnosti in glavne kontroverze v pedagoških interpretacijah, Sodobna pedagogika, 63 (2012) 4, 16-36.

${ }^{60}$ Rousseau, Emil..., 11.

${ }^{61}$ Kroflič, Rousseaujev..., 31.

${ }^{62}$ Ibid, 30.

${ }^{63}$ Goran GRETIĆ, Sloboda i zakonodavstvo umne volje. Rousseau i Kant, Politička misao: časopis za politologiju, 49 (2013) 4, 109-127.
} 
its validity determined by other didactic principles, especially the principles of education and systematic teaching. Rousseau's main contribution to didactics has not yet come to life in our schools. Implement learning material also as a means of developing student activity. "Do not comply with his wishes because he demands it, but because he needs it «. ${ }^{64}$ The student, who until then had been only an object of teaching, thus became actively involved in his own education..$^{65} \mathrm{~J}$. J. Rousseau is fully committed to love. He protects the child from social demands, follows only the child's needs and allows him to experience what he will experience on the way to his own goals. He allows him freedom in researching the learning material and trusts in it. He sees him as good.

\subsection{Johann Heinrich Pestalozzi}

Johann Heinrich Pestalozzi built his educational concept on the belief that true education is possible only in the family, because only the family environment is a truly natural environment. The love of parents and the appropriate emotional climate are crucial in this, without which, according to him, neither lessons nor education are possible. A school can perform its function only if it is designed according to a family model. This referred to the emotional climate. In the feeling of love, Pestalozzi saw the most powerful means of education. His conception of this emotion differed from the Christian conception in that he acknowledged only natural religion. His conception of this emotion differed from the Christian conception in that he acknowledged only natural religion. For him, it was about irrational love, which allows the emotional dependence of the student on the educator and thus his subordination. Pestalozzi's purpose was to improve the spiritual position of the people by freely relaxing and developing their natural potentials. ${ }^{66}$

\subsection{The Kin's School}

The Kin's School is also one of the most modern pedagogical approaches. Here, the child is already regarded as a man. Teaching is based on the holistic development of personality: man is a warrior, a teacher, he is a prophet who serves another. There are no bad grades. If someone does not pass the exam, it means that the student did not understand the material, or the material was not explained to him by the right person. ${ }^{67}$ The Kin's School was built by the students themselves and they take care of it themselves. They write textbooks

\footnotetext{
${ }^{64}$ Kroflič, Rousseaujev..., 32.

${ }^{65}$ Rousseau, Emil..., 20-24.

${ }^{66}$ Edvard PROTNER, Pedagogika in izobrazba učitelja med razsvetljenstvom in neohumanizmom, Sodobna pedagogika, 47 (1996) 1-2, 24-38.

${ }^{67}$ Karakuma SAMAI, Ta svet ali jaz sem vesolje, Šmarješke Toplice, Stella, 2016, 58-60.
} 
and teach instead of teachers. And this with all zeal and a deeper insight into the substance. The Slovak doctor of pedagogical sciences Imelda Trochtova is convinced that this can be attributed to their activities, which alternate by changing the attention of the left and right halves of the brain. ${ }^{68}$ The student has as much time as he needs to master a certain knowledge. Unburdened learning also applies to this pedagogical concept. Their schedule is structured to alternate mental activities with physical ones. ${ }^{69}$ Otherwise, as the foundation of every family, Anastasia, who also described the idea of the Kin's School, defends the 'vastness of love'. It is a property that a family maintains, designs, creates and grows its own food from kin to kin. It encourages humanity to gradually return to coexistence with nature. Through books, she worked with the aim of awakening just the feeling of love in people. Academician Mikhail Petrovich Shchetinin, who founded the Kin's School, formulated 6 principles of pedagogy: information field, phylogenetic mind, harmonious personality, communication, motivation and synergistic approach. His philosophy is based on these principles and on an upbringing that seeks to remove any blockages found in a child's mentality. ${ }^{70}$

\subsection{Socrates}

Socrates was a pedagogical genius who lived from 469 to 399 BC. »Caring for the soul« is, according to Socrates' new proclamation, a great task given to every man. Every Athenian should strive to be more considerate, better, more refined than he is. ${ }^{71}$ Socrates ${ }^{6}$ work is a historical prototype of individual pedagogy. He strives to shape the individual young man and his goal is to call a deeper grain of the soul to the surface and to root him. The direction he therefore holds is from the individual to the people's community. However, the individual pedagogy is completed in the entire life of the community and the individual does not reach the right peak if the whole lifestyle of his community is not in order. ${ }^{72}$ Here love is manifested in transcending oneself. To Socrates, the surplus is important, which one is supposed to advocate for oneself. What kind of mental surplus one is supposed to achieve, however, is a matter of his individual pedagogy? So, according to this pedagogical concept, surpluses don't have to be the same for everyone. It is important to him that one follows his soul of unity.

\footnotetext{
${ }^{68}$ Sanja TOŠEV, Ruska rodovna šola, Šolski razgledi, 60 (2009) 19, 7.

${ }^{69}$ Ibid.

${ }^{70}$ Tošev, Ruska..., 7.

${ }^{71}$ Karel OZVALD, Zgodovina pedagoške kulture v antični dobi, Nova Gorica, Branko, 2002, 72.

${ }^{72}$ Ibid, 73.
} 


\subsection{Finnish pedagogical concept}

At the end there is also Finnish pedagogical concept. Tom Stehlík says that the well-being of children is crucial for Finnish society and culture. Relationships between students, teachers, parents, and even educational administrators are based on trust. This is called pedagogical love. The concept of pedagogical love stems from the assumption that humans are basically emotional beings and that reason and will are often secondary impulses of interest. ${ }^{73}$ There is a lot of emphasis on play. Learning through play is also reflected in the ability of children to learn to use different strategies such as conceptualization, reasoning and problem solving. Playing can provide many opportunities to develop such strategies, especially when children are encouraged to take on the role of an expert. In the role of an expert, children believe that they are free and act in accordance with their wishes and knowledge, and in this way, they will be successful. Thus, children are problem solvers and problem generators and seek new challenges. ${ }^{74}$ A teacher who is aware of pedagogical love as a way of teaching will strive for a balance between keeping students in constant dependence and allowing complete independence: Pedagogical love speaks of interdependence, that is, acknowledging and accepting that we need others. This two-way relationship between teacher and student also requires that the teacher recognizes that teaching is personal, relational and dependent on his personality and the influence of their orientations. ${ }^{75}$

\subsection{Christian love in pedagogy}

In the end, we especially emphasize Christian love in pedagogy. Although Christianity developed more complex models of love (nomos, eros, agape) in its encounter with the Hellenistic and Gnostic-Oriental traditions, as well as the concept of a person, this has not been reflected in pedagogical theory and practice for a long time. After all, this argument is confirmed by the fact that the concept of a child as a ,special being/person' was only invented in the $17^{\text {th }}$ century, ${ }^{76}$ and in pedagogical theory it is more seriously affirmed by emerging psychology in the early twentieth century. ${ }^{77}$ This is an important topic beyond the scope of this article and should be addressed in a stand-alone article.

\footnotetext{
${ }^{73}$ Tom STEHLIK, Is 'pedagogical love' the secret to Finland's educational success? (30.05.2016), http://www.aare.edu.au/blog/?p=1578 (28.07.2020).

${ }^{74}$ Pirkko HYVONEN, Play in the School Context? The Perspectives of Finnish Teachers, Australian Journal of Teacher Education, 36 (2011) 8, 49-67.

${ }^{75}$ Stehlik, Is 'pedagogical...

${ }^{76}$ Phillipe ARIES, Otrok in družinsko življenje v starem režimu, Ljubljana, Studia Humanitatis, 1991, 31.

${ }^{77}$ Kroflič, Eros in vzgoja..., 232.
} 


\section{Conclusion}

Based on the founders of some pedagogical concepts, we have learned how they protect the child in a mental and spiritual sense. Those pedagogical concepts are important for us, but they are not the only one existing. The founders of the pedagogical concepts we have described are a model for the development of pedagogical knowledge that is, in a sense, eternal. After all, it is man's mission to learn to love and respect everyone. This was well known to Socrates, Steiner, Montessori and Komensky, who we especially highlight, as their findings are extremely important to us and we understand and accept them as important advocates of love (pedagogical eros) in education.

It would be also crucial to look at the development of the concept of love in pedagogical concepts also from the chronological point of view of the whole history. Due to the importance and breadth of a given problem, we see the need to define this in a separate article in the future.

\section{Maja Hmelak* - Karakuma Samai** \\ Tematika ljubavi u različitim pedagoškim konceptima \\ Sažetak}

Tema ljubavi se kroz povijest nalazi u mnogim pedagoškim konceptima gdje su je detaljno istraživali razni pedagoški teoretičari i praktičari, a mnogi su je također uključili u svoje odgojno-obrazovne koncepte. Važna je s gledišta djeteta i njegove uključenosti u sam odgojno-obrazovni proces, a za pravilno uvođenje ljubavi u sam proces potreban je empatičan i stručno osposobljen učitelj i odgajatelj. Pregledom brojnih znanstvenih i stručnih radova autorice su istražile uključenost teme ljubavi i utvrdile da se ona pojavljuje u brojnim pedagoškim konceptima. Ti su koncepti detaljno predstavljeni, kritički su vrednovani te stručno analizirani i uspoređeni. Autorice su također utvrdile da je za uvođenje teme ljubavi presudna uloga učitelja i odgajatelja i njihov primjer kojeg učenici i djeca slijede.

Ključne riječi: dijete, ljubav, odgajatelj, pedagoški koncepti, učitelj.

\footnotetext{
* Izv. prof. dr. sc. Maja Hmelak, Sveučilište u Mariboru, Pedagoški fakultet; Koroška cesta 160, SL-2000 Maribor, Slovenija.

*** Karakuma Samai, dipl. odgoj. pred. djece; postdiplomantica programa Pedagogija, Sveučilište u Mariboru, Filozofski fakultet; Maistrova ulica 14, 1270 Litija, Slovenija.
} 